\title{
PENGARUH MOTIVASI KERJA TERHADAP KINERJA KARYAWAN DALAM ISLAM (STUDI PADA PT. BOSOWA BERLIAN MOTOR KOTA PALOPO)
}

\author{
Muzayyanah Jabani ${ }^{1}$ \\ Dzulkarnain Lubis Andri ${ }^{2}$ \\ muzayyanahjabani@gmail.com
}

\begin{abstract}
In this study, the formulation of the problem is whether work motivation affects employee performance in Islam, simultaneously and partially on employee performance at PT. Bosowa Berlian Motor Palopo City. The hypothesis proposed that there is an effect of work motivation simultaneously and partially on employee performance at PT. Bosowa Berlian Motor Kota Palopo. This study aims to determine the effect of work motivation on employee performance at PT Bosowa Berlian Motor. This study uses a direct survey method to the company by going directly to the field accompanied by distributing questionnaires that have been compiled. And the analysis method used in this research is simple regression analysis. The sampling technique used is saturated sampling technique, namely the sampling technique when all members of the population are used as a sample. This is often done when the population is relatively small, less than 30 (thirty) people. The total population used is 26 employees. Based on the results of this study, motivation has a significant effect on employee performance at PT Bosowa Berlian Motor, indicated by a significant value of $\mathrm{p}=0.012$ smaller than $\alpha=0.05(0.012<0.05)$ with a regression coefficient. amounting to 0.490 . In connection with the results of hypothesis testing, the results of this study indicate the influence of work motivation and work ability both simultaneously and partially. The effect of the research results shows a positive direction, which means that better work motivation and good work abilities will improve employee performance. Motivation to work in Islam solely hopes for the blessing of Allah SWT, by doing business, being grateful for the blessings that have been given, and doing righteous deeds, motivation to work to get pious deeds in the world. working in Islam is only for the pursuit of "worldly bonuses" but also as a pious human practice towards eternity.
\end{abstract}

Keywords: work motivation; Employee performance

\section{ABSTRAK}

Dalam penelitian ini Rumusan Masalah adalah adakah pengaruh motivasi kerja terhadap kinerja karyawan dalam Islam, secara simultan dan parsial terhadap kinerja karyawan pada PT. Bosowa Berlian Motor Kota Palopo. Hipotesis yang diajukan ada pengaruh motivasi kerja secara simultan dan parsial terhadap kinerja karyawan pada PT. 
Bosowa Berlian Motor Kota Palopo.Penelitian ini bertujuan untuk mengetahui pengaruh motivasi kerja terhadap kinerja karyawan pada PT Bosowa Berlian Motor. Penelitian ini menggunakan metode survey langsung ke perusahaan melalui cara mendatangi langsung ke lapangan dengan disertai menyebarkan kuesioner yang telah disusun. Dan Metode analisis yang digunakan dalam penelitian ini yakni analisis regresi sederhana, Adapun teknik sampling yang digunakan adalah teknik sampling jenuh yaitu teknik penentuan sampel bila semua anggota populasi digunakan sampel. hal ini sering dilakukan bila jumlah populasi relatif kecil, kurang dari 30 (tiga puluh) orang. Jumlah populasi yang digunakan sebanyak 26 karyawan.. Berdasarkan hasil penelitian ini motivasi berpengaruh signifikan terhadap kinerja karyawan pada PT Bosowa Berlian Motor, ditunjukkan dengan nilai signifikan $\mathrm{p}=0,012$ lebih kecil dari $\alpha=0,05(0,012<0,05)$ dengan koefisien regresi sebesar 0,490 . Berkaitan dengan hasil pengujian hipotesis, maka hasil penelitian ini menunjukan adanya pengaruh dari motivasi kerja dan kemampuan kerja baik secara serempak maupun secara parsial. Pengaruh yang ditimbulkan dari hasil penelitian menunjukan arah yang positif, yang berarti bahwa motivasi kerja yang lebih baik dan adanya kemampuan kerja yang baik akan meningkatkan kinerja karyawan. Motivasi kerja dalam islam semata-mata mengharapkan ridho dari Allah SWT, dengan cara berusha, mensyukuri nikmat yang telah diberikan, dan melakukan amalanamalan shaleh, Motivasi bekerja untuk mendapatkan amalan saleh di dunia. bekerja dalam Islam itu hanya mengejar "bonus duniawi" namun juga sebagai amalan saleh manusia untuk menuju kepada kekekalan.

Kata Kunci : Motivasi kerja; Kinerja

Karyawan

\section{PENDAHULUAN}

\section{A. Latar Belakang}

Perekonomian nasional di Indonesia tidak lepas dari globalisasi yang telah melanda dunia akhir-akhir ini. Hal ini dibuktikan dengan semakin banyaknya perusahaan-perusahaan baru yang secara otomatis mengakibatkan persaingan dunia usaha yang semakin ketat, baik pada tingkat nasional maupun tingkat internasional. Dampak yang secara langsung dirasakan adalah perkembangan dunia usaha dalam negeri yang mengalami kemajuan yang cukup pesat baik yang dilakukan oleh pemerintah maupun swasta. 
Setiap organisasi atau perusahaan memerlukan sumber daya untuk mencapai tujuannya. Sumber daya merupakan sumber energi, tenaga, kekuatan (power) yang diperlukan untuk menciptakan daya, gerak, aktivitas, kegiatan, dan tindakan. Sumber daya tersebut terdiri atas sumber daya alam, sumber daya finansial, sumber daya manusia, sumber daya ilmu pengetahuan, dan sumber daya teknologi. Diantara sumber daya tersebut, sumber daya terpenting adalah sumber daya manusia. Sumber daya manusia merupakan sumber daya yang digunakan untuk menggerakkan dan menyinergikan sumber daya lainnya untuk mencapai tujuan organisasi. Tanpa sumber daya manusia, sumber daya lainnya menganggur (idle) dan kurang bermanfaat dalam mencapai tujuan organisasi. ${ }^{1}$

Dalam suatu sistem perusahaan, potensi sumber daya manusia pada hakekatnya merupakan salah satu modal dan memegang peran penting dalam mencapai tujuan perusahaan. Oleh karena itu perusahaan perlu mengelola sumber daya manusia sebaik mungkin. dengan manajemen sumber daya itu sendiri. Manajemen sumber daya manusia biasa didefinisikan sebagai proses untuk merekrut, mengembangkan, memotivasi, serta mengevaluasi keseluruhan sumber daya manusia yang diperlukan perusahaan dalam mencapai tujuannya. ${ }^{2}$ Dengan demikian di dalam manajemen sumber daya manusia dibutuhkan juga seorang karyawan, dimana karyawan tersebut juga memiliki tugas yang besar untuk menjalankan aktivitas organisasi agar produktivitas kerja yang diharapkan oleh organisasi tercapai. Karyawan merupakan orang-orang yang bekerja pada suatu perusahaan atau pada instansi pemerintahan atau badan usaha dan memperoleh upah atas jasanya.

Untuk meningkatkan kinerja karyawan, perusahaan juga dapat meningkatkan motivasi kerja para karyawan karena motivasi dapat mempengruhi seseorang untuk memberikan dorongan kepada seseorang untuk melakukan sesuatu. Faktor-faktor yang dapat meningkatkan kinerja karyawan seperti dikatakan Hezberg ialah motivator. Faktor-faktor itu terdiri dari faktor keberhasilan, penghargaan, faktor pekerjaannya sendiri, rasa tanggung jawab, dan faktor peningkatan. ${ }^{3}$ Adapun pengertian performance sering diartikan sebagai kinerja, hasil kinerja atau prestasi kinerja. Kinerja mempunyai makna yang lebih luas, bukan hanya menyatakan sebagai hasil kerja, tetapi bagaimana proses kerja berlangsung. Kinerja adalah

\footnotetext{
${ }^{1}$ Wirawan, Evaluasi Kinerja Sumber Daya Manusia, (Jakarta, Salemba empat), h. 1

${ }^{2}$ Erni Tisnawati Sule dan Kurniawan Saefullah, Pengantar Manajemen, Ed. 1, (Cet. 1; Jakarta: kencana, 2005) h. 194

${ }^{3}$ Mifta Thoha, PerilakuOrganisasi, Konsep Dasar Dan Aplikasinya, Ed, 1.(Cet. 23, Jakarta : Rajawali Pers, 2014) h.231
} 
tentang apa yang dikerja dan bagaimana cara mengerjakannya. Kinerja merupakan hasil pekerjaan yang mempunyai hubungan kuat dengan tujuan organisasi. ${ }^{4}$

Pekerjaan merupakan sarana untuk memperoleh rezeki dan sumber penghidupan yang layak. Dapat pula dikatakan bahwa bekerja adalah kewajiban dan kehidupan. Islam menjadikan bekerja sebagai hak dan kewajiban individu. Rasulullah menganjurkan bekerja dan berpesan agar melakukannya sebaik mungkin. Rasulullah juga berpesan untuk berlaku adil dalam menentukan upah kerja dan menepati pembayarannya. Fondasi utama yang diletakkan Islam dalam mengatur perolehan kehidupan (makanan pokok) manusia adalah dengan bekerja. ${ }^{5}$ Dalam Al-Qur'an: QS At-Taubah: 105 (tentang pekerjaan yang mulia dan menjadikannya sebagai sumber rezeki yang halal) yang berbunyi :

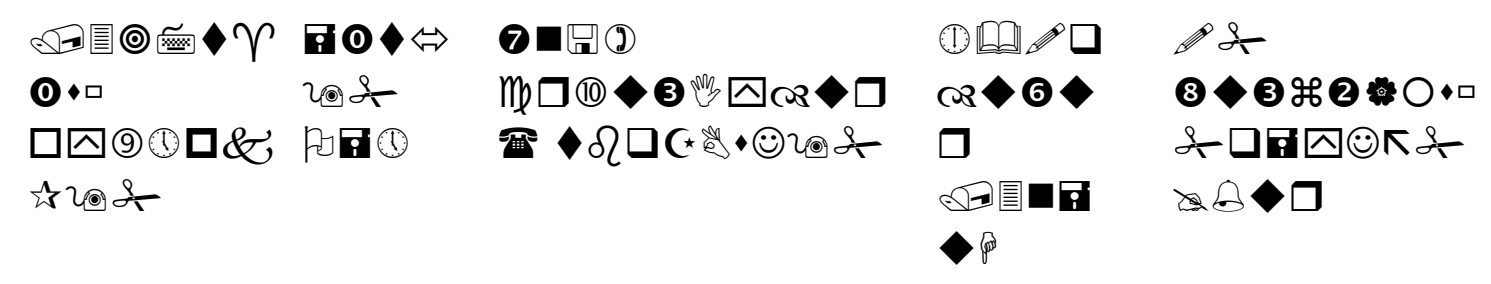

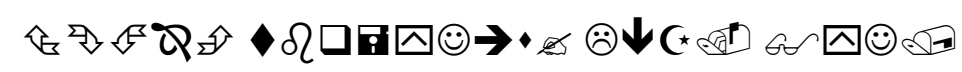

Terjemahan:

Dan Katakanlah, "Bekerjalah kamu, Maka Allah dan Rasul-Nya serta orang-orang mukmin akan melihat pekerjaanmu itu, dan kamu akan dikembalikan kepada (Allah) yang mengetahui akan yang ghaib dan yang nyata, lalu diberitakan-Nya kepada kamu apa yang telah kamu kerjakan". 6

Setiap manusia memiliki motivasi kerja masing-masing, tetapi ada pula sebagian orang yang lebih giat daripada orang lain. Kebanyakan orang mau bekerja keras jika tidak menemui hambatan dalam mengaplikasikan apa yang diharapkan. Selama dorongan kerja itu kuat, semakin besar pula peluang seseorang untuk konsisten pada tujuan kerja dan kehidupannya. Ada pula yang menyukai dorongan tanpa mengharapkan imbalan, sebab ia menemukan kesenangan dan kebahagiaan dalam perolehan kondisi yang dihadapi dan mengatasi kondi sulit itu.

PT. Bosowa Berlian Motor di Kota Palopo adalah perusahaan yang bergerak dibidang perniagaan/penjualan jasa, khususnya penjualan dan perbaikan kendaraan merek Mitsubishi. Melihat akan pentingnya pengaruh motivasi terhadap kinerja karyawan, maka sudah

\footnotetext{
${ }^{4}$ wibowo, Manajemen kinerja, (Ed,3-5, Jakarta, Rajawali Pers: 2011) h. 2

5 Abdul Hamid Mursi, SDM Yang Produktif, "Pendekatan AL-QUR'AN dan Sains", Cet.1, (Jakarta:
} 
Gema Insani Press, 1997)

${ }^{6}$ Departemen Agama RI, Al-Qur'an daqn Terjemahannya (Jakarta: CV, DIponegoro, 2005) 
sepatutnya motivasi diberikan kepada setiap karyawan untuk dapat mencapai tujuan yang ingin dicapai, baik organisasi swasta maupun organisasi pemerintah. Sehingga pemberian motivasi dapat mendorong semangat kerja karyawan dan pada akhirnya dapat menyelesaikan tugas-tugasnya.

B. Rumusan Masalah

Berdasarkan latar belakang di atas, maka penulis dapat mengemukakan pokok permasalah dalam penelitian ini, yaitu :

Adakah pengaruh motivasi kerja terhadap kinerja karyawan PT, Bosowa Berlian Motor di Kota Palopo ?

C. Hipotesis

Dalam pembahasan ini penyusun mencoba memberikan jawaban sementara yaitu :

Terdapat pengaruh motivasi terhadap kinerja karyawan PT. Bosowa Berlian Motor Kota Palopo.

\section{KAJIAN PUSTAKA}

A. Motivasi

a. Jenis-Jenis Motivasi

1. Motivasi positif (insentif positif), manajer memotivasi bawahan dengan memberikan hadiah kepada mereka yang berprestasi baik. Dengan motivasi positif ini semangat kerja bawahan akan meningkat, karena manusia pada umumnya senang menerima yang baik-baik saja.

2. Motivasi negative (insentif negative), manajer memotivasi bawahannya dengan memberikan hukuman kepada mereka yang pekerjaannya yang kurang baik (prestasi rendah). Dengan motivasi negativ ini semangat kerja bawahan dalam jangka waktu pendek akan meningkat, karena mereka takut dihukum, akan tetapi untuk waktu jangka yang panjang dapat berakibat kurang baik.

Dalam praktik kedua jenis motivasi di atas sering digunakan oleh manajer suatu perusahaan. penggunaannya harus tepat dan seimbang, supaya dapat meningkatkan semangat kerja karyawan. Yang menjadi masalah ialah "kapan motivasi positif atau motivasi negativ" itu efektif merangsang gairah kerja karyawan. Motivasi positif efektif untuk jangka panjang, 
sedangkan motivasi negativ untuk jangka pendek saja. Tetapi manajer harus konsisten dan adil dalam penerapannya.

b. Metode Motivasi

1. Metode-metode motivasi (Direct Motivation), adalah motivasi (materiil dan nonmaterial) yang diberikan secara langsung kepada setiap individu karyawan untuk memenuhi kebutuhan dan kepuasannya. jadi sifatnya khusus seperti memberikan pujian, penghargaan, bonus, piagam dan lain sebagainya.

2. Motivasi tidak langsung (indirect motivation), adalah motivasi yang diberikan hanya merupakan fasilitas-fsilitas yang mendukung serta menunjang gairah kerja/kelancaran tugas, sehingga para karywan betah dan bersemangatmelakukan pekerjaannya. Misalnya, kursi yang empuk, mesin-mesin yang baik, ruang kerja terang dan nyaman, suasana dan lingkungan pekerjaan yang baik, penetapan karyawan yang tepat dan lain-lain. Motivasi tidak langsung ini besar pengaruhnya untuk merangsang semangat karyawan, sehingga produktivitas kerja meningkat.

\section{B. Motivasi Kerja Dalam Pandangan Islam}

Motivasi adalah kekuatan dari dalam diri setiap individu yang menggerakkan individu untuk berbuat. Jadi suatu kekuatan atau keinginan yang datang dari dalam hati nurani manusia untuk melakukan suatu perbuatan tertentu.

Untuk mengetahui motivasi kerja dalam Islam, kita perlu memahami terlebih dahulu fungsi dan kedusukan bekerja. Mencari nafkah dalam Islam adalah sebuah kewajiban. Islam adalah agama yang fitrah, yang sesuai dengan kebutuhan manusia, diantaranya kebutuhan fisik. Dan salah satu cara memenuhi kebutuhan fisik itu dengan cara bekerja. ${ }^{7}$ Secara syariah Islam, kehidupan manusia tidak dibatasi hanya di dunia saja. Ada kehidupan lain yang lebih penting setelah melewati alam fana ini, yaitu kehidupan di alam akhirat. Gerak aktivitas manusia di dunia ini, haruslah dimotivasi oleh adanya keyakinan atas kehidupan akhirat ini. seperti: sabar, taubat, tawakkal, akhlak yang baik, shalat, puasa, jihad, dan lain sebagainya.

Motivasi kerja dalam Islam itu adalah untuk mencari nafkah yang merupakan bagian dari ibadah. Motivasi kerja dalam Islam bukanlah untuk mengejar hidup hedonis, bukan juga untuk status, apalagi untuk mengejar kekayaan dengan segala cara. Dengan demikian motivasi kerja dalam Islam, bukan hanya memenuhi nafkah semata tetapi sebagai kewajiban beribadah

\footnotetext{
${ }^{7}$ Ananto Pramandhika, Motivasi Kerja Dalam Islam, (Studi Kasus pada Guru TPQ di Kecamatan Semarang Selatan), (Semarang: 2011)
} 
kepada Allah setelah ibadah fardlu lainnya. Bekerja untuk mencari nafkah adalah hal yang istimewa dalam pandangan Islam.

Dalam memahami Islam secara komprehensif, biasanya dikaji tiga landasan utama sistem Islam, yaitu rukun iman, rukun Islam, dan ihsan. Tiga landasan utama tersebut dapat dilihat sebagai suatu tahapan dalam menjalani kebidupan yaitu: dasar fundamental, yaitu memantapkan diri dengan iman dan mengabdi kepada Allah SWT, melaksanakan pekerjaan dengan model rukun Islam (arkanul Islam) dan melaksanakan pekerjaan tersebut sesempurna mungkin dengan perasaan diawasi dan selalu bersama. Dengan sisi pandang yang lain, tiga landasan utama tersebut, sering juga disebutkan sebagai aqidah, syariah dan akhlaq. Aqidah adalah dasar fundamental, suatu keyakinan keagamaan yang dianut seseorang dan menjadi landasan segala bentuk aktivitas, sikap, pandangan dan pegangan hidupnya. Istilah akidah ini identik dengan iman. Syariah adalah aturan pelaksanaan pekerjaan yaitu ketentuan hukum Allah yang diturunkan kepada para Nabi dan Rasul untuk umatnya. Istilah syariah biasa diidentikkan dengan istilah Islam. Sedangkan akhlaq adalah pola tingkah laku dalam melaksanakan pekerjaan tersebut, yaitu tingkah laku yang lahir dari manusia dengan sengaja, tidak dibuat-buat dan telah menjadi kebiasaan. Istilah ini dapat disamakan dengan ihsan.

Ayat-ayat dibawah ini menunjukkan bahwa adanya motivasi kerja yang utuh dalam Islam. Motivasi bekerja untuk mendapatkan amalan saleh di dunia. bekerja dalam Islam itu hanya mengejar "bonus duniawi" namun juga sebagai amalan saleh manusia untuk menuju kepada kekekalan.

Motivasi kerja dalam Islam antara lain :

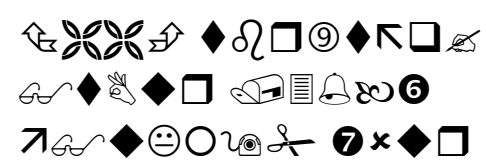

Terjemahan

"Dan di langit terdapat (sebab-sebab) rezkimu dan terdapat (pula) apa yang dijanjikan kepadamu (QS. Adz Dzariyaah : 22)

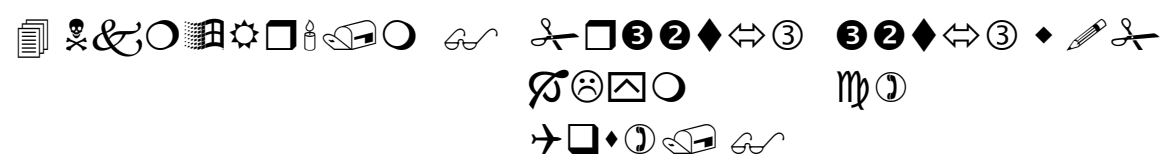

Terjemahan

“Sesungguhnya Allah tidak merobah Keadaan sesuatu kaum sehingga 
mereka merobah keadaan yang ada pada diri mereka sendiri. (QS. Ar-Ra'd : 11) 
Dari ayat tersebut diatas menjelaskan bahwa sungguh sangat tegas Allah dalam memberikan penjelasan kepada manusia dalam hal perbaikan nasib mereka, yakni sekali-kali Allah tak akan merubah nasib suatu kaum sehingga mereka sendiri yang berusaha merubahnya. Dalam hal ini niat yang disertai dengan keikhlasan itulah inti sebenarnya dalam kehidupan dan pekerjaan manusia dapat bergerak dan bekerja dengan tekun dan mempunyai tujuan tertentu yaitu mardatillah (keridhaan Allah) itulah yang dicari dalam semua urusan. Dari situlah akan lahir nilai keberkahan yang sebenarnya dalam kehidupan yang penuh dengan curahan rahmat dan nikmat yang banyak dari Allah. Inilah golongan yang diistilahkan sebagai golongan yang tenang dalam ibadah, ridha dengan kehidupan yang ditempuh, serta optimis dengan janji-janji Allah.

\section{Kinerja Karyawan}

a. Pengertian Kinerja Karyawan

Kinerja adalah sebuah kata dalam Bahasa Indonesia dari kata dasar "kerja" yang menerjemahkan kata dari bahasa asing prestasi. Bisa pula berarti hasil kerja. ${ }^{8}$

Dalam kamus besar bahasa Indonesia "kinerja" berarti sesuatu yang dicapai; prestasi yang diperhatikan, atau kemampuan kerja. ${ }^{9}$ Amstrong dan Baron menjelaskan bahwa kinerja merupakan sarana untuk mendapat hasil yang lebih baik dari organisasi, tim, dan individu dengan cara memahami dan mengelola kinerja dalam kerangka tujuan dan standar, dan persyaratan atribut yang disepakati. ${ }^{10}$

D. Kerangka Pikir

Kerangkah pikir dalam penelitian ini adalah sebagai berikut:

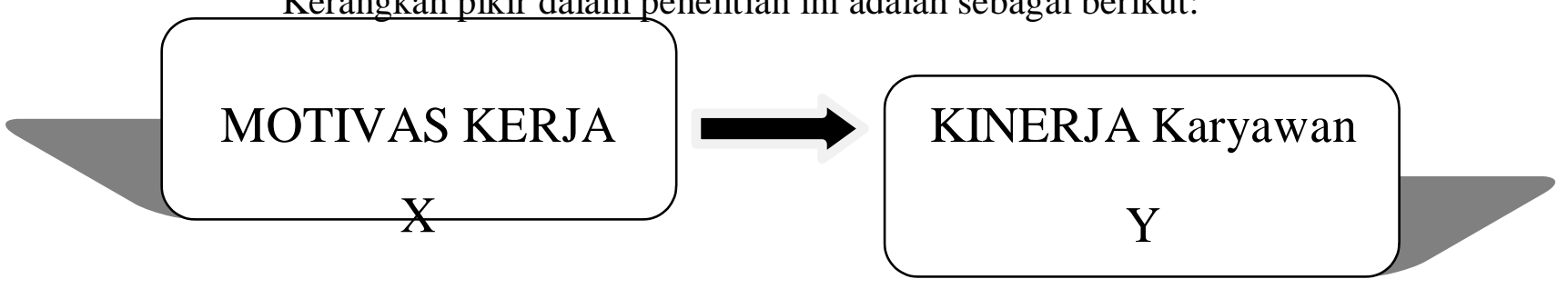

Penjelasan :

Kerangka pikir diatas menggambarkan bahwa dalam manajemen kepemimpinan perusahaan PT. Bosowa Berlian Motor Palopo memberikan motivasi kepada karyawan yang

${ }^{8}$ https://id.wikipedia.org/wiki/Kinerja

${ }^{9}$ Tim Penyusun Kamus Pusat Pembinaan dan pengembangan Bahasa. Kamus Besar Bahas Indosnesia, (Cet. 9, Jakarta Balai Pustaka 1997), h. 503

${ }^{10}$ Hilal Mahmud, Model Pengembangan Kinerja Guru Pada Sma Negri Di Kota Palopo, (Pascasarjana Uin Alauddin Makassar: 2015), h. 53 
dapat mempengaruhi tingkat kinerja karyawan didalamnya. yang dalam konsep akan berimplikasi pada penjualan di perusahaan tersebut.

Pada penelitian ini akan dicari kebenaran dari hipotesis yang menyatakan bahwa ada pengaruh dari motivasi terhadap kinerja karyawan dan pengaruh lain yang memotivasi kinerja pada karyawan di perusahaan tersebut.

\section{Metode Penelitian}

A. Pendekatan dan Jenis Penelitian

Dalam penelitian ini menggunakan penelitian lapangan yaitu dangan meneliti langsung pada objek yang akan diteliti yaitu para karyawan PT. Bosowa Berlian Motor Kota Palopo. Penelitian ini menggunakan jenis penelitian kuantitatif, dimana jenis kuantitatif merupakan penelitian yang lebih berdasarkan pada data dihitung untuk menghasilkan suatu pemikiran. Isi rencana analisis data selalu didasarkan pada rencana penelitian yang telah dirumuskan dan data sudah siap diolah. ${ }^{11}$

Sedangkan pendekatan penelitian yang digunakan dalam penelitian ini bersifat asosiatif (hubungan), penelitian asosiatif merupakan penelitian yang bertujuan untuk mengetahui hubungan antara dua variable ataulebih. ${ }^{12}$

B. Lokasi penelitian

Penelitian yang dilakukan peneliti berlokasi Jln. Jendral Sudirman No. 65, Kelurahan Tompotikka, Kecamatan Wara kota palopo.

\section{a. Populasi Dan Sampel}

Populasi adalah wilayah generalisasi yang terdiri atas, obyek/subjek mempunyai kualitas dan karakteristik tertentu yang ditetapkan oleh peneliti untuk dipelajari dan kemudian ditarik kesimpulan. ${ }^{13}$

Jadi populasi bukan hanya orang, tetapi juga objek dan benda-benda alam yang lain. Populasi juga bukan sekedar jumlah yang ada pada objek/subjek yang dipelajari, tetapi meliputi seluruh karakteristik/sifat yang dimiliki oleh subjek dan objek lain. Sehingga penelitian membahas tentang Pengaruh Motivasi Terhadap Kinerja Karyawan dengan mengambil populasi pada perusahaan PT. Bosowa Berlian Motor Kota Palopo dengan jumlah populasi 26 (dua puluh enam) karyawan.

11 Nugroho J. Setiadi, Perilaku Konsumen (konsep dan implikasi untuk strategi dan penelitian pemasaran) cet. Pertama, (Jakarta: kencana, ed. 1, 2003), h. 28

${ }^{12}$ Sugiono, Metode Penelitian Bisnis, (Bandung: Alfabeta, 2005), h. 11

${ }^{13}$ Sugiono, Metode Penelitian Administrasi, (Bandung, Alfabeta : 2013), h.91 
Sampel adalah bagian dari jumlah dan karakteristik yang dimiliki oleh populasi tersebut. ${ }^{14}$ Dalam penelitian ini, teknik sampling yang digunakan adalah teknik sampling jenuh yaitu teknik penentuan sampel bila semua anggota populasi digunakan sampel. hal ini sering dilakukan bila jumlah populasi relatif kecil, kurang dari 30 (tiga puluh) orang. ${ }^{15}$

C. Sumber Data, Variabel, Dan Skala Pengukuran

1. Sumber Data

Sumber data dalam penelitian ini menggunakan sumber data primer. Data primer adalah data yang diperoleh dari sumber-sumber asli. Sumber asli disini diartikan sebagai sumber pertama dari mana data tersebut diperoleh. ${ }^{16}$ Data primer Dalam penelitian ini didapat dengan memberikan kuosioner pada karyawan PT. Bosowa Berlian Motor Kota Palopo.

2. Variabel

Variabel penelitian adalah suatu hal yang berbentuk apa saja yang ditetapkan oleh peneliti untuk dipelajari sehingga diperoleh informasi tentang hal tersebut kemudian di tarik kesimpulannya. Variabel dalam penelitian kualitatif ini dibagi menjadi dua, yaitu variable dependen (terikat) dan Variabel Independen (bebas).

Secara teoritis variabel didefinisikan sebagai berikut sebagai atribut seseorang, atau objek yang mempunyai "variasi" antara satu orang dengan orang lain atau dengan satu objek dengan objek yang lain menurut Hatch dan Farhady. Variabel juga dapat merupakan atribut dari bidang keilmuan atau kegiatan tertentu. ${ }^{17}$ Dilihat dari bentuk hubungan klausa, yaitu sebab akibat, maka variabel tersebut dibedakan menjadi dua kategori yaitu variabel bebas (X) dan Variabel Terikat (Y). Variabel Bebas (X) adalah variabel perilaku pengaruh terhadap variabel terikat. Variabel (Y) adalah variabel yang timbul akibat variabel bebas atau respon dari variabel bebas. Oleh sebab itu variabel terikat menjadi tolak ukur atau indicator keberhasilan variable bebas. $^{18}$

\footnotetext{
${ }^{14} \mathrm{Ibid}$.

${ }^{15}$ ibid. h. 96
}

16 Suharsimi Arikunto, Prosedur Penelitian, Suatu Pendekatan Praktek, (PT. Rineka, Cipta Jakarta:2011), h.107

${ }^{17}$ Sugiono, Metode Penelitian Pendidikan, (Bandung: Alfabeta, 2009), h. 60

${ }^{18}$ Nanasudjana, Tuntunan Penyusunan Karya Ilmiah Makalah-Skripsi-disertasi, (Bandung: Sinar Baru Argasindo, 2007), h. 24 
Dalam Penelitian ini terdapat dua variable yang akan diteliti yaitu Variabel bebas $(\mathrm{X})$ dan variable terikat $(\mathrm{Y})$ atau tidak bebas Yaitu " pengaruh motivasi (X) terhadap Kinerja Karyawan (Y). Dengan bentuk paradigma adalah sebagai berikut :

$$
\begin{aligned}
& X=\text { Motivasi Kerja } \\
& Y=\text { Kinerja Karyawan }
\end{aligned}
$$

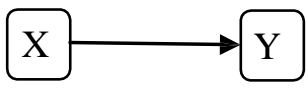

3. Instrumen Penelitian

Instrument penelitian adalah alat yang digunakan untuk mengumpulkan data yang dibutuhkan oleh peneliti, disini alat yang digunakan adalah angket. Angket atau kuisioner adalah daftar pertanyaan yang didistribusikan melalui pos untuk diisi dan dikembalikan atau dapat di bawah pengawasan peneliti.

Instrument penelitian adalah alat yang digunakan untuk menangkap data penelitian dan menggali variabel yang diteliti. sesudah itu barulah dipaparkan prosedur pengembangan instrument pengumpulan atau pemilihan alat dan bahan yang digunakan dalam penelitian. Dengan cara ini akan terlihat apakah instrumentinstrument yang digunakan sesuai dengan variable yang di ukur, paling tidak ditinjau dari segi isinya. ${ }^{19}$

Instrumen yang digunakan untuk mengukur variable penelitian ini dengan menggunakan skala likert 5 poin. ${ }^{20}$ Skala ini digunakan untuk mengukur sikap pendapat, dan persepsi seorang atau kelompok orang tentang fenomena social. ${ }^{21}$ Jawaban responden berupa pilihan dari pilihan dari lima alternative yang ada, yaitu :

1. SS : Sangat setuju, memiliki nilai 5

2. $\mathrm{S}$ : setuju memiliki nilai 4

3. $\mathrm{R}$ : Ragu-ragu, memiliki nilai 3

4. TS : tidak setuju, memiliki nilai 2

5. STS : sangat tidak setuju, memiliki nilai 1

D. Tekenik Pengumpulan Data

Untuk memperoleh data yang diperlukan dalam penelitian ini maka pelaksanaannya dilakukan dengan cara:

\footnotetext{
${ }^{19}$ Tim Penyusun, Pedoman Penyusunan Skripsi, (Tulungagung: IAIN Tulungagung, 2014), h. 24

${ }^{20}$ ibid, h. 135

${ }^{21}$ ibid, h. 194
} 
a. Penelitian kepustakaan (library Research).

Penelitian yang dilakukan dengan cara mengumpulkan data melalui beberapa literature, artikel, karya ilmiah dan bahan analisis yang berkaitan dengan penelitian ini.

b. Penelitian lapangan (Field Research).

Adalah penelitisn yang dilakukan secara langsung pada objeknya, untuk mendapatkan data yang dibutuhkan secara lain. Dalam proses pengumpulan data, penulis menggunakan kuesioner, yaitu daftar pertanyaan yang didistribusikan untuk diisi dan dikembalikan atau dapat juga dijawab dibawah pengawasan peneliti. ${ }^{22}$

E. Teknik Analisis Data

Rancangan analisis data dalam penelitian ini untuk menguji hipotesis yang telah dirumuskan adalah analisis Regresi Linear Sederhana. Model persamaan Regresi Linear Sederhana adalah seperti berikut ini :

$$
\begin{aligned}
& \mathrm{Y}=\mathrm{a}+\mathrm{bX}+\mathrm{e} \\
& \mathrm{Y}=\text { varaiabel Motivasi Kerja (Dependen) } \\
& \mathrm{X}=\text { Variabel Kinerja Karyawan (independen) } \\
& \mathrm{a}=\text { konstanta } \\
& \mathrm{b}=\text { koefisien regresi }
\end{aligned}
$$

Analisis data adalah proses mencari dan menyusun secara sistematis data yang telah diperoleh dari hasil catatan lapangan dan dokumentasi dengan cara mengorganisasikan data ke dalam kategori, menjabarkan ke dalam unit-unit, melakukan sintesa, menyusun pola, memilih mana yang penting dan yang akan dipelajari dan membuat kesimpulan sehingga mudah di pahami oleh diri sendiri maupun orang lain

\section{Analisis Univariat}

Analisis univariat bertujuan untuk menjelaskan atau mendeskripsikan karakteristik setiap variable penelitian. Bentuk penyajian data dengan distribusi frekuenzi dan presentase.

2. Analisis Bivariat

Analisis bivariat terkait dengan melihat variabel dependen penelitian dengan grafik regresi linear sederhana dengan $\alpha=0,05$

a. Apabila hasil hitung regresi $\mathrm{p}$ value $>0,05$ maka Ho diterima dan $\mathrm{Ha}$ ditolak

\footnotetext{
${ }^{22}$ Nasution S, Metode Research, (Jakarta: bumi aksara, 2001), h.128
} 
b. Apabila hasil hitung regresi $\mathrm{p}$ value $<0,05$ maka Ho ditolak dan $\mathrm{Ha}$ diterima

\section{Pembahasan dan Hasil Penelitian}

A. Gambaran Umum Perusahaan

Perusahaan PT. Bosowa Berlian Motor merupakan salah satu perusahaan yang bergerak dalam bidang pemasaran mobil merek yang terletak di Jalan Jendral Sudirman Kota Palopo Sulawesi Selatan. Penelitian ini mengambil sampel karyawan PT.Bosowa Berlian Motor Cabang Kota Palopo sebanyak 25 orang.

1. Analisis Univariat

Tabel 4.4

Distribusi Responden berdasarkan Motivasi Karyawan

\begin{tabular}{|c|c|c|} 
Motivasi & Frequency & Percent \\
Rendah & 17 & 65.4 \\
Tinggi & 9 & 34.6 \\
Total & 26 & 100.0
\end{tabular}

Sumber : Data Primer, 2016

Tabel 4.4 di atas menunjukkan penilaian motivasi terhadap karyawan di PT Bosowa Berlian Motor, responden dengan motivasi tinggi sebanyak 9 responden $(34,6 \%)$ dan responden dengan motivasi rendah sebanyak 17 responden $(65,4 \%)$ dari 26 responden yang bekerja di PT Bosowa Berlian Motor

Tabel 4.5

Distribusi Responden berdasarkan Kinerja Karyawan

\begin{tabular}{|c|c|c|} 
Kinerja & Frequency & Percent \\
Kurang Baik & 17 & 65.4 \\
Baik & 9 & 34.6 \\
Total & 26 & 100.0
\end{tabular}

Sumber : Data Primer, 2016

Tabel 4.5 di atas menunjukkan penilaian kinerja karyawan di PT Bosowa Berlian Motor, responden dengan kinerja baik sebanyak 9 responden $(34,6 \%)$ dan kinerja kurang baik sebanyak 17 responden $(65,4 \%)$ dari 26 responden yang bekerja di PT Bosowa Berlian Motor

2. Analisis Bivariat

Analisis bivariat dimaksudkan untuk mengetahui pengaruh variabel independen yaitu motivasi dengan variabel dependen yaitu kinerja karyawan di PT Bosowa Berlian Motor 
Untuk melihat pengaruh motivasi terhadap kinerja karyawan di PT Bosowa Berlian Motor Kota Palopo digunakan uji regresi. Hal ini dapat dilihat pada tabel berikut :

a. Pengaruh motivasi terhadap kinerja

Pengaruh antara motivasi dengan kinerja karyawan disini bertujuan untuk mengetahui apakah ada atau tidaknya pengaruh antara motivasi dengan kinerja karyawan Bosowa Berlian Motor Kota Palopo.

Tabel 4.6

Pengaruh Motivasi Terhadap Kinerja Karyawan

PT Bosowa Berlian Motor Kota Palopo

Tahun 2016

\begin{tabular}{|c|c|c|c|c|c|c|c|}
\hline \multirow{3}{*}{$\begin{array}{c}\text { Motivasi } \\
\text { Kerja }\end{array}$} & \multicolumn{4}{|c|}{ Kinerja Karyawan } & \multirow{2}{*}{\multicolumn{2}{|c|}{ Total }} & \multirow{3}{*}{$\begin{array}{c}\mathrm{P} \\
\text { (Value) }\end{array}$} \\
\hline & \multicolumn{2}{|c|}{ Kurang Baik } & \multicolumn{2}{|c|}{ Baik } & & & \\
\hline & $\mathrm{n}$ & $\%$ & $\mathrm{n}$ & $\%$ & $\mathrm{~N}$ & $\%$ & \\
\hline Rendah & 14 & $8.24 \%$ & 3 & $33.3 \%$ & 17 & $65.4 \%$ & \\
\hline Tinggi & 3 & $33.3 \%$ & 6 & $66.7 \%$ & 9 & $34.6 \%$ & \\
\hline Total & 17 & $65.4 \%$ & 9 & $34.6 \%$ & 26 & $100 \%$ & \\
\hline
\end{tabular}

Sumber : Data Primer, 2016

Tabel 4.6 di atas menunjukkan bahwa dari 9 responden $(34,6)$ yang menyatakan motivasi karyawan tinggi, dimana karyawan yang baik kinerjanya sebanyak 3 responden $(33,3 \%)$ dan yang kurang baik kinerjanya sebanyak 14 responden $(8,24 \%)$. Sedangkan dari 17 responden $(65,4 \%)$ yang menyatakan motivasi karyawan rendah, dimana karyawan yang baik kinerjanya sebanyak 6 responden $(66,7 \%)$ dan yang kurang baik kinerjanya sebanyak 3 responden $(33,3 \%)$.

Hasil uji regresi dengan linier sederhana menunjukkan bahwa nilai $\rho=0,012$, karena nilai $\rho=<0,05$ maka Ho ditolak dan Ha diterima sehingga dapat dikatakan bahwa ada pengaruh 
antara motivasi terhadap kinerja karyawan PT Bosowa Berlian Motor Kota Palopo tahun 2016.

b. Uji linieritas

Uji linieritas digunakan untuk mengetahui hubungan motivasi kerja dengan kinerja karyawan liniear atau tidak. Jika terdapat hubungan linier maka digunakan analisis regresi linier.

Dimana hipotesis untuk uji linieritas adalah :

$H o$ : Tidak ada hubungan yang linier antara motivasi kerja dengan kinerja karyawan PT Bosowa Berlian Motor.

$H_{a}$ : Ada hubungan yang linier antara motivasi kerja dengan kinerja karyawan PT

Bosowa Berlian Motor.

Uji linier dengan bantuan SPSS 20, didapatkan hasil sebagai berikut :

Tabel 4.7

Output Uji Linieritas SPSS 20

ANOVA

\begin{tabular}{|l|c|c|c|c|c|}
\hline \multicolumn{1}{|c|}{ Model } & $\begin{array}{c}\text { Sum of } \\
\text { Squares }\end{array}$ & Df & $\begin{array}{c}\text { Mean } \\
\text { Square }\end{array}$ & $\mathrm{F}$ & Sig. \\
1 Regression & 1.414 & 1 & 1.414 & 7.591 & $.011^{\mathrm{a}}$ \\
Residual & 4.471 & 24 & .186 & & \\
Total & 5.885 & 25 & & &
\end{tabular}

Berdasarkan tabel 4.7 di peroleh nilai $\mathrm{F}=7.591$ dengan tingkat signifikansi 0,011. Tingkat Sig. Akan dibandingkan dengan 0,05 (dengan taraf signifikansi $\alpha=5 \%$ ), untuk mengambil keputusan maka menggunakan kriteria pengujian sebagai berikut :

1. Jika nilai sig. $<\alpha$ maka Ho ditolak

2. Jika nilai sig. $>\alpha$ maka $\mathrm{H}_{\mathrm{a}}$ ditolak

$0,011<0,05$ maka Ho ditolak artinya ada hubungan yang linier antara motivasi kerja terhadap kinerja karyawan. Karena nilai sig. 0,011 lebih kecil dari 0,05 maka model regresi dapat digunakan untuk memprediksi pengaruh motivasi kerja terhadap kinerja karyawan PT Bosowa Berlian Motor. 
c. Pengujian Hipotesis

Hipotesis dalam penelitian ini adalah :

Ho :Tidak ada pengaruh yang signifikan antara motivasi kerja terhadap kinerja karyawan PT Bosowa Berlian Motor

$\mathrm{H}_{\mathrm{a}}$ : Ada pengaruh yang signifikan antara motivasi kerja terhadap kinerja karyawan PT Bosowa Berlian Motor

Untuk mencari persamaan regresinya dengan bantuan SPSS 20 didapat hasil sebagai berikut :

Tabel 4.7

Output Uji Analisis Regresi Linear Sederhana SPSS 20

Coefficients $^{\mathrm{a}}$

\begin{tabular}{|c|c|c|c|c|c|}
\hline & $\begin{array}{r}\text { Unsta } \\
\text { Coe }\end{array}$ & $\begin{array}{l}\text { fdardized } \\
\text { ficients }\end{array}$ & $\begin{array}{l}\text { Standardized } \\
\text { Coefficients }\end{array}$ & & \\
\hline Model & B & Std. Error & Beta & $\mathrm{t}$ & Sig. \\
\hline (Constant) & .176 & .105 & & 1.686 & .105 \\
\hline Kinerja & .490 & .178 & .490 & 2.755 & .011 \\
\hline
\end{tabular}

Berdasarkan hasil di atas diperoleh nilai konstanta pada kolom B. Sehingga dapat diperoleh persamaan regresi sebagai berikut :

$$
\begin{aligned}
& Y=a+b X \\
& Y=0.176+0.490 X
\end{aligned}
$$

Untuk mengetahui apakah persamaan regresi di atas dapat digunakan untuk memprediksi besarnya variabel terikat $(\mathrm{Y})$ berdasarkan variabel bebas $(\mathrm{X})$ di lakukan pengujian hipotesis untuk mengetahui signifikansi antara dua variabel.

Berdasarkan hasil penelitian dengan menggunakan uji chi-square menunjukkan bahwa dari 9 responden $(34,6)$ yang menyatakan motivasi karyawan tinggi, dimana karyawan yang baik kinerjanya sebanyak 3 responden $(33,3 \%)$ yang berarti bahwa motivasi kerja yang lebih baik dan adanya kemampuan kerja yang baik akan meningkatkan kinerja karyawan, dan dari 9 responden $(34,6 \%)$ yang menyatakan motivasi karyawan tinggi terdapat 14 responden 
$(8,24 \%)$ dengan kinerja karyawan kurang baik, yang berarti masih ada yang dapat menyebabkan kurang baiknya kinerja karyawan, dimana perlu menciptakan suatu kondisi yang dapat memberikan kepuasan kebutuhan karyawan, mengingat walaupun motivasi tinggi tetapi kemampuan kerja yang dimaksud belum optimal dalam mencapai kinerja yang diharapkan oleh perusahaan sehingga kinerja karyawan kurang baik.

Sedangkan dari 17 responden $(65,4 \%)$ yang menyatakan motivasi kerja rendah, dimana karyawan yang baik kinerjanya sebanyak 6 responden $(66,7 \%)$ keberhasilan dan kecakapan pelaksanaan pekerjaan dalam suatu organisasi sangat bergantung pada kinerja karyawannya. Dan dari 17 responden $(65,4 \%)$ yang menyatakan motivasi kerja rendah dengan kinerja kurang baik sebanyak 3 responden $(33,3 \%)$. yang berarti motivasi kerja yang rendah sangat menentukan kinerja karyawan dalam sebuah perusahaan. Responden yang memiliki motivasi rendah dengan kinerja kurang baik karena responden melihat dan merasa belum terampil dalam berbicara dan memiliki tingkat pengetahuan yang baik dalam memberikan kinerja yang di inginkan sesuai perusahaan PT.Bosowa Berlian Motor.

Hasil uji hipotesis dengan bantuan statistika dengan menggunakan Regresi Linier menunjukkan bahwa, nilai $p=0.011$. Hal ini berarti $p<\alpha=0.05$. Karena nilai $p$ lebih kecil dari $(\alpha=0.05)$ maka $\mathrm{H}_{0}$ ditolak dan Ha diterima. Ini berarti bahwa ada pengaruh motivasi kerja terhadap kinerja karyawan di PT Bosowa Berlian Motor Kota Palopo tahun 2016.

Hasil penelitian ini menunjukkan bahwa variabel motivasi memiliki nilai koefisien regresi sebesar 0,490, dan nilai probilitas sebesar 0,011 yang berarti motivasi mempengaruhi produktivitas kerja karyawan secara signifikan. Selain itu motivasi memiliki nilai Beta sebesar 0,490 yang berarti motivasi kerja berpengaruh terhadap kinerja karyawan sebesar 49,0\%. Dalam hal ini motivasi kerja karyawan merupakan bentuk kesediaan untuk berusaha keras mencapai tujuan dengan memperhatikan usaha memuaskan beberapa kebutuhan, serta upaya untuk memperbaiki dan membentuk pengetahuan, sikap dan perilaku karyawan sehingga karyawan tersebut secara sukarela berusaha bekerja secara kooperatif dengan para karyawan lainnya untuk meningkatkan kinerjanya.

Hal ini sejalan dengan penelitian yang telah dilakukan oleh Mahardika (2013), Musliani (2012), dimana motivasi berpengaruh dan signifikan terhadap kinerja karyawan.

Dalam penelitian yang dilakukan oleh Mahardika (2013) motivasi berpengaruh signifikan terhadap kinerja karyawan pada PT. AXA Financial Indonesia, ditunjukkan dengan nilai signifikansi t sebesar 0,000 lebih kecil dari $\alpha=0,05(0,000<0,05)$ dengan koefisien regresi sebesar 0,514. Motivasi ekstrinsik berpengaruh signifikan terhadap kinerja karyawan pada PT. AXA Financial Indonesia, ditunjukkan dengan nilai signifikansi t sebesar 
0,000 lebih kecil dari $\alpha=0,05(0,000<0,05)$ dengan koefisien regresi sebesar 0,475. Motivasi intrinsik dan motivasi ekstrinsik secara simultan berpengaruh signifikan terhadap kinerja karyawan pada PT. AXA Financial Indonesia, ditunjukkan dengan nilai signifikansi F sebesar 0,000 lebih kecil dari $\square=0,05(0,000<0,05)$ dan mampu memberikan kontribusi terhadap variabel kinerja karyawan sebesar 64,3\%.

Hal ini sejalan dengan hasil penelitian Musliani (2013) menunjukkan bahwa faktor yang mempengaruhi kinerja karyawan PT Citra Sarana Sejahtera Kota palopo dipengaruhi oleh gaya kepemimpinan, kepuasan kerja dan lingkungan kerja. Dari hasil analisa data dengan Chisquare di peroleh nilai $\mathrm{p}=0.002$ yang berarti lebih kecil dari nilai $\alpha(0.05)$ dengan demikian dapat disimpulkan bahwa ada hubungan antara motivasi kerja dengan kinerja karyawan di PT Citra Sarana Sejahtera Kota Palopo sedangkan pada pengalaman kerja dengan kinerja karyawan dapat dilihat analisa Chi-Square diperoleh nilai $\mathrm{p}=0.000$ yang berarti lebih kecil dari nilai $\alpha(0,05)$ dengan demikian dapat disimpulkan bahwa ada hubungan antara pengalaman kerja dengan kinerja karyawan di PT Citra Sarana Sejahtera Kota Palopo. Dan adapun Faktor dominan yang mempengaruhi kinerja karyawan antara motivasi kerja dengan pengalaman kerja PT Citra Sarana Sejahtera Kota Palopo adalah faktor motivasi kerja. ${ }^{23}$

Dari beberapa penelitian diatas menunjukkan bahwa ada pengaruh antara motivasi terhadap kinerja karyawan PT Bosowa Berlian Motor Kota Palopo tahun 2016.

\section{KESIMPULAN}

Berdasarkan hasil penelitian dan pembahasan yang di uraikan pada bab sebelumnya, maka penulis menarik kesimpulan atas hasil analisis tersebut yaitu sebagai berikut :

Hasil uji regresi dengan linier sederhana menunjukkan bahwa nilai $\rho=0,012$, karena nilai $\rho=<0,05$ maka Ho ditolak dan Ha diterima sehingga dapat dikatakan bahwa ada pengaruh antara motivasi terhadap kinerja karyawan PT Bosowa Berlian Motor Kota Palopo tahun 2016.

Dari hasil analisis di atas diperoleh persamaan regresi yaitu $\mathrm{Y}=0.176+0.490 \mathrm{X}$. Jadi persamaan regresi dapat digunakan untuk meramalkan besarnya variabel terikat (Y) berdasarkan variabel $(\mathrm{X})$. Persamaan regresi $=0.176+0.490$ yang berarti motivasi kerja berpengaruh terhadap kinerja karyawan.

${ }^{23}$ Musliani, Hubungan Motivasi Kerja dan Pengalaman Kerja Terhadap Kinerja karyawan PT. Citra Sarana Sejahtera Palopo, Skripsi (Program Studi Ekonomi Islam Jurusan Syariah STAIN : Palopo, 2013) 


\section{SARAN}

Setelah menyimpulkan hasil analisis, maka selanjutnya penulis mengemukakan saransaran yang kiranya dapat berguna yaitu :

1. Disarankan perlunya pimpinan perusahaan memberikan kompensasi yang sesuai dengan kompetensi karyawan dan memberikan motivasi bagi karyawannya agar prestasi kerjanya lebih meningkat dalam melaksanakan ketentuan-ketentuan yang berlaku.

2. Mengingat bahwa variabel motivasi kerja berpengaruh terhadap kinerja karyawan maka disarankan kepada pihak perusahaan untuk senantiasa memberikan motivasimotivasi kepada karyawan. 


\section{Daftar Pustaka}

Arikuntono Suharsimi, Prosedur Penelitian, Suatu Pendekatan Praktek, PT. Rineka, Cipta Jakarta:2011

Departemen Agama RI, Al-Qur'an daqn Terjemahannya Jakarta: CV, DIponegoro, 2005

Mahmud Hilal, Model Pengembangan Kinerja Guru Pada Sma Negri Di Kota Palopo, Pascasarjana Uin Alauddin Makassar: 2015), h. 53

Mifta Thoha, PerilakuOrganisasi, Konsep Dasar Dan Aplikasinya, Ed, 1.Cet. 23, Jakarta : Rajawali Pers, 2014

Mursi Abdul Hamid, SDM Yang Produktif, "Pendekatan AL-QUR'AN dan Sains", Cet.1, Jakarta: Gema Insani Press

Musliani, Hubungan Motivasi Kerja dan Pengalaman Kerja Terhadap Kinerja karyawan PT. Citra Sarana Sejahtera Palopo, Skripsi Program Studi Ekonomi Islam Jurusan Syariah STAIN : Palopo, 2013

Nanasudjana, Tuntunan Penyusunan Karya Ilmiah Makalah-Skripsi-disertasi, Bandung: Sinar Baru Argasindo, 2007

Nasution S, Metode Research, Jakarta: bumi aksara, 2001

Pramandhika Ananto, Motivasi Kerja Dalam Islam, Studi Kasus pada Guru TPQ di Kecamatan Semarang Selatan, Semarang: 2011

Setiadi Nugroho J., Perilaku Konsumen konsep dan implikasi untuk strategi dan penelitian pemasaran,cet. Pertama, Jakarta: kencana, ed. 1, 2003

Sule Erni Tisnawati dan Kurniawan Saefullah, Pengantar Manajemen, Ed. 1, Cet. 1; Jakarta: kencana, 2005

Sugiono, Metode Penelitian Bisnis, Bandung: Alfabeta, 2005

Tim Penyusun Kamus Pusat Pembinaan dan pengembangan Bahasa. Kamus Besar Bahas Indosnesia, Cet. 9, Jakarta Balai Pustaka 1997

Tim Penyusun, Pedoman Penyusunan Skripsi, Tulungagung: IAIN Tulungagung, 2014

wibowo, Manajemen kinerja, Ed,3-5, Jakarta, Rajawali Pers: 2011

Wirawan, Evaluasi Kinerja Sumber Daya Manusia, Jakarta, Salemba empat 